\title{
Civilisations
}

Revue internationale d'anthropologie et de sciences

humaines

$63 \mid 2014$

L'Ancestralité revisitée

\section{God, the Warlord and the Way of the Ancestors}

On the Intertwinement of Christianity and Ancestry in Hendrik Witbooi's Politico-Religious Mission of the 1880s (Southwest Africa)

\section{Christine Hardung}

\section{(2) OpenEdition}

\section{Journals}

Electronic version

URL: http://journals.openedition.org/civilisations/3685

DOI: $10.4000 /$ civilisations. 3685

ISSN: 2032-0442

\section{Publisher}

Institut de sociologie de l'Université Libre de Bruxelles

\section{Printed version}

Date of publication: 30 September 2014

Number of pages: 81-98

ISSN: 0009-8140

Electronic reference

Christine Hardung, "God, the Warlord and the Way of the Ancestors », Civilisations [Online], 63 | 2014

Online since 30 September 2018, connection on 20 April 2019. URL : http://journals.openedition.org/ civilisations/3685 ; DOI : 10.4000/civilisations.3685 


\title{
God, the Warlord and the Way of the Ancestors
}

\author{
On the Intertwinement of Christianity and Ancestry in Hendrik Witbooi's \\ Politico-Religious Mission of the 1880s (Southwest Africa)
}

\author{
Christine HARDUNG
}

\begin{abstract}
In the 1840's, one of the Oorlam groups, the Khowese (Witbooi), crossed the Orange River and migrated from the Cape Colony to the southern part of present-day Namibia. A few decades later, Hendrik Witbooi had a vision instructing him to lead his followers north on a mission from God. Witbooi claimed the sole right of passage for a path which he saw as having been created by their ancestors. The path of the ancestors represented a territorial claim. But the way of the ancestors also represented an immaterial direction and guidance which would justify military expansion into Herero territory. Hendrik Witbooi assembled his followers, the Witkam, and led them on several military campaigns north during the 1880 's.

Based on the Witkam, with their particular combination of detraditionalization and charismatic leadership on one hand and Witbooi's reference to ancestry on the other, this piece will take a broader look at the relationship between violence and religion in the armed conflicts and raids conducted by the Nama/Oorlam in the $19^{\text {th }}$ century.
\end{abstract}

Keywords: ancestry, Christianity, violence, Nama/Oorlam, South West Africa.

Résumé : Dans les années 1840, les Khowese (Witbooi), l'un des groupes Oorlam, passent le fleuve Orange dans la région frontalière nord de la Colonie du Cap et migraient vers le sud de la Namibie actuelle. Quelques décennies plus tard, Hendrik Witbooi, futur warlord et figure charismatique, a une vision lui donnant pour mission divine de mener son peuple vers le nord. Witbooi revendique le droit de passage exclusif sur un chemin qu'il considère comme ayant été créé par ses ancêtres. Revendication territoriale, le chemin des ancêtres est aussi un objectif symbolique et la justification de l'expansion militaire sur le territoire Herero. Hendrik Witbooi rassemble ses partisans, les Witkam, et les mène dans plusieurs campagnes militaires vers le nord dans les années 1880.

Prenant l'exemple des Witkam, avec leur combinaison particulière entre détraditionnalisation et leadership charismatique d'une part et la référence aux ancêtres d'autre part, cet article aborde la relation entre violence et religion dans les razzias et conflits armés conduites par les Nama/ Oorlam au cours du $19^{\text {ème }}$ siècle.

Mots-clés : ancêtres, christianisme, violence, Nama/Oorlam, Sud-Ouest africain. 
$\mathrm{D}$

uring the late $18^{\text {th }}$ and early $19^{\text {th }}$ century, the Oorlam, a people of a variety of backgrounds - deserters, escaped slaves and Khoekhoe deprived of their pasturelands by the Boer expansion into their territory - retreated to the northwestern border region of the Cape Colony. Their social existence was based on the fundamental experience of violence. They organized themselves into militarized, socio-political units, the socalled komandos, and in several waves, migrated to the southern part of present-day Namibia. ${ }^{1}$ In the 1840 s, one of the Oorlam groups, the Khowese (Witbooi), crossed the Orange River. Spatially and socially de-territorialized and almost completely impoverished after a lengthy period of wandering in the frontier region on both sides of the river, they asked//Oaseb, the chief of 'Great Namaqualand' to provide them with a place to settle. They finally settled majoritarily in Gibeon in 1863.

A few decades later, Hendrik Witbooi, a descendant of the first migrant generation, had a vision which instructed him to lead his followers north on a mission from God - a mission that thus justified the raids and armed conflicts involved. Witbooi claimed the sole right to tread a path which he saw as having been determined by the ancestors of the group, and which led to a strategically well-situated redoubt in the mountains (Schwarz 1889: 157). Thus, the path of the ancestors was on the one hand a territorial claim, and beyond that, an immaterial direction and guidance which was seen as justifying military expansion into Herero territory. The goal was to unite the Nama and Oorlam and to lead them north, as their ancestors had foreseen and desired. Hendrik Witbooi then during the 1880 s assembled his followers, the Witkam, and led them on several military campaigns northward. ${ }^{2}$

Hendrik Witbooi revolutionized the social foundations of the komando. Although the core of his own komando was composed of his "own people," the Witboois, under his concept of the Following, the fact of belonging to a certain Nama-Oorlam group was replaced as the determining factor for the composition of a komando by the consciousness of each individual to be fighting for a "higher cause." Hence, anyone who shared that conviction could become a Witkam, i.e. a member of Witbooi's following. For the Witkam, the charismatic Hendrik Witbooi was "not only the leader, but indeed a prophet," whom, according to the assessment of a contemporary, "they followed in blind obedience" (Schwarz 1889: 162). The trader Conradt, who sold ammunition to Witbooi during the 1880 s, wrote that "He was the only Hottentot captain who really had power over his men. The others were only obeyed if their men felt like obeying them." (Conradt 2006 [1905-06]: 127). Witbooi subordinated the raiding and combat activities of the looting warriors in his komando to strict rules: sexual abstinence prior to a campaign, no looting raids except when he authorized them, punishment of thievery even during a campaign, the return of all illegally looted goods to their owners, and the rejection of all magical practices. But the warlord not only imposed military discipline on the komando, he also linked it to religion. Witbooi's komando can be seen as a "charismatic community of violence," which, as a combat - or looting - formation,

1 See Dedering 1997, Kienetz 1977, 52ff., Lau 1987, 19ff, Penn 2005, Wallace and Kinahan 2011, $50 \mathrm{ff}$.

2 Lau 1889, pp. III-XI. On the military and raiding campaigns of Hendrik Witbooi in central Namibia during the 1880s, see Henrichsen 2011, pp. 166ff. 
was on a "divine mission." The old Following based on small-group identity was thus transformed into one based on faith (Hardung and Trotha 2014: 292).

Focusing on the Witkam, with their particular combination of de-traditionalization and charismatic leadership on one hand, and Witbooi's reference to ancestry on the other, the present paper $^{3}$ will take a broader look at the relationship between violence and religion in the wars and raids conducted by the Nama-Oorlam during the $19^{\text {th }}$ century. It will ask how the Christian religion has been adapted and redefined by Hendrik Witbooi in order to be able to integrate it into the economy and culture of a lifestyle based on raiding as practiced by the Nama-Oorlam at the time. The paper will be limited to the 1880 s, a period "in the shadow of protection" (Wallace and Kinahan 2011: 103), when German colonial master had entered the country, but had not yet brought Namaqualand under their control. It is this period for which coeval sources can provide insight into how Hendrik Witbooi experienced and imagined ancestral power, and how he used it militarily and politically in coexistence with what he believed to be God's empowerment, handed to him to fulfil his mission.

Hendrik Witbooi's movement stands for the beginning of a process that started with the arrival of missionaries in Africa, a process in which "Christianity was Africanized, and Africa Christianized, distilling novel self-awareness on all sides" and which revealed "ways in which religion creates power and showed how people might act upon that awareness, both as colonizer and colonized" (J. Comaroff 2012: 6). His departure to the North touches upon questions of the intersectedness of "Christianity and politics, or, in more general terms, religion and the secular" (Meyer 2012: 165).

In the Namibian memorial culture, the military and political leader and prophet Hendrik Witbooi has become a symbol of resistance against colonial rule in southwestern Africa, particularly of the trauma of the genocidal war conducted by the German colonial forces against the Nama-Oorlam and the Herero in the early $20^{\text {th }}$ century (e.g. Hillebrecht 2004, Kößler 2010). His famous "diaries"4 reveal his political farsightedness and also his fundamental internal struggle over the relationship between violence and Christian ethics. In these notes, Witbooi does not reflect upon the Khoisan religion; that topic is a discursive blank space. Nonetheless, the indigenous concept of religion remained present in Witbooi's politico-religious practice, particularly in the significance he attributed to the ancestors and to their instructions.

The belief to have been sent by God, the empowerment of religious experience, the claiming of moral authority in times of crises are all characteristic of leaders of prophetic movements. ${ }^{5}$ Witbooi's both politically and religiously motivated actions bore the elements of such a personality. ${ }^{6} \mathrm{He}$ has been characterized as a deeply

3 This article is based on a research project (Gewaltgemeinschaft, Krieg und politische Herrschaft. Ein Vergleich von Gewaltgemeinschaften und Häuptlingtum am Beispiel der Nama-Oorlam und Herero) at the University of Siegen. The project was funded by the German Research Foundation (DFG) 2010-13 in the framework of research group 1101 on "Communities of Violence" (Gewaltgemeinschaften). I would like to thank Phil Hill for the translation of the text.

4 The Hendrik Witbooi papers, annotated by Brigitte Lau (1989).

5 See i.a. Anderson and Johnson 1995, Redding 2010.

6 On "Witbooi, the Prophet" Dedering 1997. Loth (1987) examines Witbooi's prophetic movement in the context of African messianic movements. 
religious Christian. His relationship to Christianity and to the missionaries of the Rhenish Missionary Society ${ }^{7}$ has been described in detail, both from a missionaryhistorical-theological and a historical-anthropological perspective, and is documented in the source material. ${ }^{8}$ I would like to concentrate on an as yet little considered aspect, and examine the hidden side of Hendrik Witbooi's understanding of religion. While following an approach within the anthropology of Christianity that assumes the coeval existence of Christianity and African religious traditions (i.a. Meyer 2012), I will trace elements of indigenous religiosity in his religious practice, particularly his relationship with his ancestors.

Recent studies which address transcultural phenomena of religions from a socioanthropological perspective argue for an abandonment of dichotomization and in favor of placing forms of religiosity which have emerged in spatially disparate situations into a "common globalized spatial/temporal" texture ( $c f$. Tall 2012: 30). Referring to processes of transculturation and transfer history which resulted from the Protestant missionary activities in Africa (i.a. Beidelman 1982, Meyer 1999, Altena 2003, Wirz 2003), this paper seeks to show how two religious systems, the Christian and, in its rudiments, the Khoekhoe religion, interacted with one another more than they intermingled ${ }^{9}$.

Elements of indigenous religions in which prophecy was a "common vehicle for religious innovation, revitalization, or reformation" (Tishken 2007: 1471) can often be identified in African Christian prophetic movements. The prophetic movement of the Wikham, "lacked," as Dedering (1993: 75) emphasizes, "any patterns of 'nativism' and it did not promise the reconstruction of real or reinvented 'traditional' cultural elements." Nonetheless, the ancestral presence in Witbooi's mission bears witness to the pervasiveness of the pre-Christian past in Witbooi's politico-religious movement.

\section{In motion: ancestry and pre-Christian beliefs}

Ancestor worship is a core element of most pre-colonial religious activity, as well as many postcolonial societies of sub-Saharan Africa (McCall 1995, Cole and Middelton 2001, Asante and Mazama 2009: 53, Jules-Rossette 1994: 54). Even more, if the term worship is not restricted "to elaborate ceremonies involving ritualized sacrifices," but used instead "in its broader sense of reverence and respect," then ancestor worship in its "claims of communication between the dead and their descendants" can be assumed to be a "universal aspect of religion" (Steadman, Palmer and Tilley 1996: 64).

The source basis on this topic is rather thin, despite the central significance given to ancestorhood in African religious practice, ${ }^{10}$ which can equally be assumed for the

7 The Rhenish Mission Society began its activity in Southwest Africa in 1842.

8 Kleinschmidt 1894, Menzel 2000, Möhlig 2007, Reeh 2000.

9 For the Khoekhoe communities of the Cape, this question is posed by Elbourne 1992.

10 Mudimbe and Kilonzo (2012), who discuss the relationship of religious and religion, see no reason for critical questioning when referring to 'African religious-practice.' On the other hand, they do question the notion of 'African religion' in certain contexts as 'essentialising' and argue for a 'cautious' use of attribution 'African.' 
Khoekhoe in pre-Christian and early-Christian times. Even if the Nama apparently had no collective ancestor cult ( $c f$. Glocke 2001: 113 and 184, Schapera 1930: 395), some evidence can be found for personal ancestral-related practices. There are descriptions of Nama traveling long distances to visit gravesites and praying at the graves of their ancestors (cf. Schapera 1930: 172 and 374, Hahn 1881 [2000]: 42 and 46), even if they had long since abandoned the old places of habitation once located there. Like sources of water, graves were not only spatial fixed points, but also part of a social and memorial topography.

The linguist Theophilus Hahn, who had grown up as a missionary's son among the Nama, told of meeting a group of traveling Nama, among them a "woman of rank" whom he knew well, in the hunting grounds at the edge of the Kalahari. Surprised to meet a woman in this waterless area, he asked her for the reason for her journey. She told him that she had lost her cattle to the drought and to looters, and was in great difficulty, so that she was on her way to the grave of her father, who had died nearby. "I am going to pray and weep there," "11 Hahn quotes the woman. "He will hear my voice, and he will see my tears, and he will give luck to my husband, who is now out ostrich-hunting ..." "But your father is dead, how will he hear?" Hahn responded. "Yes, he is dead," answered the woman, "But he only sleeps! We Khoikhoi always, if we are in trouble, go and pray at the graves of our grandparents and ancestors ..." (Hahn 1881 [2000]: 112-113).

In addition to the graves of their ancestors, the Nama went to the tombs of HeitsiEibib, "the great grandfather" (Hahn 1881 [2000]: 65), as he was addressed. HeitsiEibib, for whom - as we will see - can be found direct clues in Hendrik Witbooi's awakening experience, might have been one of the three most important beings in the pre-Christian universe of the Khoekhoe. Having "conquered and annihilated all his enemies, who killed his people," being "very clever and wise" and able to "foretell what was going to happen in the future," (Hahn 1881 [2000]: 65) Heitsi-Eibib has been figured as a protective spirit and a great powerful chief, rich in cattle, who himself fought against enemies, "a mythological ancestor living much the same sort of life as the Hottentots themselves did" (Ibid.: 386). ${ }^{12}$ Often a rogue who could take on a variety of shapes, who died in various places and was repeatedly resurrected, Heitsi-Eibib can be seen as a protective but also a tricky figure with visionary skills ( $c f$. Glocke-Daffa 2001: 114).

In the Cape Colony and in southwestern Africa, the graves of Heitsi-Eibib, which also provide evidence of the migrations of the Nama, lay generally along the wayside. Passers-by would place stones and other objects on the graves. They saw this as sacrificial offering, asking for protection for their hunts and treks or other wants. The graves consisted of piled-up hills, which the explorer Lichtenstein (1812: 214) described as being "20-30 paces". They were often located close to distinctive natural formations, which we might read as liminal spaces, such as the exit points of canyons.

11 This and all subsequent English quotes in this account are taken from the original [Trans. Note].

12 On the diversity of Heitsi-Eibib, see Schmidt (1986), who explores the complex nature of Heitsi-Eibib as fiend, bush being, trickster, God and transformer of the primeval world to the world of today. Schmidt considers his ascribed feature of ancestor as "least pronounced" (Ibid.: 233), but she sets in relation to the question of a historical genealogy. 
Peter Kolb, a German astronomer with special interest in Khoesan cultures who lived at the beginning of the $18^{\text {th }}$ century at the Cape, gave attention to the religious universe of the (Cape) Khoekhoe. "... They consider in their mind," he stressed, "that certain places are sacred, because their ancestors have received great luck at such spots. Those places are to be found in the deserts, and consist of stone heaps, others are rivers, ... and they never pass such a deserted spot or hill without offering worship to the saint who, according to their belief, inhabits the place, and who has done so much good to so many of them" (quoted from Hahn 1881 [2000]: 42).

Likewise, the explorer James Alexander, who traveled Great Namaqualand in today's Namibia in the first half of the $19^{\text {th }}$ century, mentioned ritualized activities at the graves of Heitsi-Eibib, which were perceived by contemporaries as "a form of ancestor worship". "These Namaquas thought that they came from the east. In the country there is occasionally found [...] large heaps of stones on which had been thrown a few bushes; and if the Namaquas are asked what these are, they say that Heijé Eibib, their great Father, is below the heap. ... and when they add a stone or branch to the heap, they mutter, 'Give us plenty cattle"' (Alexander 1838: 127). The same prayers for prosperity, wealth in cattle or success in hunting could evidently also be expressed at the graves of Heitsi-Eibib and at the gravesites of one's own ancestors, which would likewise be pointed toward the east. Protective powers and powers of fertility seem to have been attributed to the deity as well as to the living dead. Such "ancestral presence" (McCall 1995: 258) was inscribed in the "landscape itself" by the piles of stones found all over Great Namaqualand and beyond.

The grave mounds of ordinary mortals were covered with large stones and differed visually from the tombs of Heitsi-Eibib, on which were lain mostly smaller stones. Ordinary graves (/howas $=$ grave) also differed conceptionally from Heitsi-Eibib's graves (//Khob = Heitsi-Eibib's grave) (Schmidt 1986: 230). The latter were thought non-man-made and created by Heitsi-Eibeb himself (Ibid.). According to Hahn, the Nama imagined Heitsi-Eibib as having "lived originally in the East. ... Therefore they make the doors of their huts toward the East, where the sun and the moon rise. ... All the graves are directed towards the East, and the face of the deceased is also turned to that direction." (Hahn 1881 [2000]: 65) In the spatial symbolism - the orientation of the dwellings, tombs and dead to the east - the mythical ancestor Heitsi-Eibib lived on in the increasingly Christianized $19^{\text {th }}$-century population into the $20^{\text {th }}$ century. The act of laying down stones with a prayer on the Heitsi-Eibib graves was long continued (see Schmidt 1986: 231).

\section{The political context and the moral dilemma of the looting warrior}

The 1880s, in which the emergence of Hendrik Witbooi prophetic movement and the rise of his charismatic leadership fell, were a time characterized by massive political tensions and economic changes in the context of consolidating imperial interests and an expanding commercial capitalist system, in which the Herero participated as well. Due to a drought in $1879 / 80$ as well as political conflicts over development rights in the Windhoek area, Herero moved with their herds from central Namibia, where they lived in pre-colonial times, further south and intruded into Namaqualand. A number of unfavorable land sales by local landowners to the then entering Germans led to a further 
loss of grazing land and watering holes - both the basis for the herding culture - for the Nama-Oorlam. Their growing debt to European traders and the decimation of big game and livestock left them increasingly impoverished. Cattle raiding became the core of the Nama-Oorlam economy in the 1880s (Henrichsen 2011: 181). The growing violent conflicts between Nama-Oorlam and Herero, which also affected the Damara, turned around political supremacy, the expansion and maintenance of trade networks with the Cape Colony, access to watering holes, and, above all, cattle, the main barter against weapons and ammuntion, on which depended the loot economy of the Nama-Oorlam. ${ }^{13}$

This crisis was one important push-up factor of the "prophetic moment," which Marcia Wright defined as the "conjuncture of new and old" when analysing the Maji Maji rebellion in Eastern Africa, "in which old beliefs are reshaped to suggest a course of action to a profoundly troubled society" (1995: 124-125). For the Nama-Oorlam this was also a moral crisis. By taking over Christianity, the looting warriors were in a tension between two competing ethics, the legitimacy of their violence in the context of the warfare-and-raiding culture, and of its illegitimacy under the Christian religious code. Hendrik Witbooi's prophetic movement was thus both a reaction to the precarious political and economic situation and a reflection of the contradiction of two value systems, one of which, Christianity, both condemned the cattle-raiding culture and, at the same time, provided in its adaption to the local conditions a basis for its moral justification.

Missionary sources variously address the ambivalence of Witbooi's movement to solve the dilemma of the looting warriors of being economically dependent on raids, which were usually accompanied by violence, while at the same time questioning them from a moral standpoint. The problem came to a head in their attitude of the "Witbooi people," as missionaries reported, toward the practice of the Holy Communion, from which the former increasingly absented themselves.

Since Sub-Captain Habel Izaak wanted to have his child baptized, the question was for the first time raised why the Witkam had their children baptized, but on the other hand forbade the custom of the Holy Communion. Habel Izaak answered that it was impossible for him to follow his captain even to the point of shedding blood, then to be prepared for Holy Communion, and then to continue the same life. ${ }^{14}$

Their existence as looting warriors was tied to a Christian/Protestant-inspired lifestyle, in which the question of legitimacy of violent action was internalized, not externalized. The moral law of warfare, and with it, the hitherto practiced forms of legitimate violence, were thus subordinated to a process of "culpabilization" (Behrend 1993: 60). The individual warrior, and the group as a whole, now had to answer to God - that was the context in which the missionaries, too, condemned "misdeeds," which must have had a decisive effect on the self-image of the perpetrators of violence and also on their manner of combat.

13 Hillebrecht 2004: 144, Henrichsen 2011: 166 et seq., Wallace and Kinahan 2011: 103 3t seq.

14 RMG 2.579 C/I 1, H. Hegner, Berserba, 18 January 1894: 251, Rheinische Missionsgesellschaft (RMG), Archives of the United Evangelical Mission, Wuppertal. 
The cited passage on the congruence between two refusals, the overriding of the Sixth Commandment, and the self-imposed exclusion from the Holy Communion belongs to a series of indications to be found in missionary sources on the Eucharistic ritual and its sacred objects in the context of violence, often expressed in gestures of great symbolic power that allow for various interpretations, such as the presentation of a vessel to the missionary J. Knauer. After the destruction of the mission station at Gibeon in 1866 by the Khai//khaum (Red Nation), the missionaries had accompanied the "Gibeoners" and mediated a prisoner exchange between them and their enemies. During the search for the refuge of the pursued //Oaseb, head of the Khai//khaum, a messenger had been sent to one of //Oaseb's allies who, according to Knauer, "had also been involved in the attack on Gibeon. He ranted and cursed at me, and sent me a wooden vessel, with the message that I was to drink their blood from it." 15 It remains open whether this involved an analogy between the wooden vessel and the Eucharist chalice, and hence a local interpretation of the concept of sacrifice, such as symbolized in the Christians' Eucharistic concept, under which wine symbolizes the presence of the sacrificial blood of Christ. It would seem possible, on the other hand, to see the object sent to the missionary as an indication of "subversive pagan counter-images" to the dominant Christian discourse, in which the Eucharist, translated into local terms as "transcendent cannibalism," was integrated into a "local witchcraft discourse" (Behrend 2011) which remained obscure to the missionary.

The dynamics of religious conviction and religious practice which emerged from the plurality of religious systems also affected the Nama-Oorlam's conduct of warfare and raiding activities. With the introduction of modern firearms, the Nama-Oorlam did not in any way abandon the idea that it was the meshing of magical and otherworldly protective practices with technology and human commitment that promised the successful outcome of a warlike enterprise. Accordingly, new technologies, such as the gun, where "traditionalized," i.e. integrated into spiritual practices and ritual contexts. Protective/defensive amulets, which warriors wore around their necks were included as well. They are mentioned even in the early-17 $7^{\text {th }}$-century travel literature on the Khoekhoe of Southern Africa (Schreyer 1679/81 [1931]: 32) as Hölzchen (little pieces of wood) "carved from a certain bush" by a specialist, and burned to charcoal on one end. The warlord Hendrik Witbooi did not accept the lifestyle of his followers based on such traditional Khoisan beliefs. "Anybody who carries magic Hölzchen and wants to steal oxen is dismissed from Hendrik Witbooi's komando," 16 wrote the missionary F. Meyer, succinctly describing Witbooi's style of leadership. Presumably, Witbooi grew up with Khoisan religious beliefs before beginning to turn toward Christianity of his own accord. Radical rejection of what has hitherto been practiced often accompanies a conversion ( $c f$. Lindenfeld and Richardson 2012: 8). Hendrik Witbooi decisively rejected any form of "heathen law and custom," from which a "Christian chief," out of responsibility for "his people," had to turn away; his choice of words was very much in 
line with the language used by the Rhenish Missionary Society. "God's Word" was not merely to be externally adopted, but also "received internally." 17

Everything "heathen" was thus ultimately declared to be taboo. Tabooization generally involves the control of ideas. Ideas must be "kept busy if they are to be kept under control" (Popitz 2000: 89). In this sense, Witbooi's visions, dreams and divine inspirations can be considered "proffered ideas" (Ibid.: 90), in the same manner that myths and fairy tales supplement tabooized ideas.

Witbooi needed performative rites to fulfill the need of his followers for visible symbolism. The magical cultic objects and ritualized activities which he rejected, and which were based on a Khoekhoe "culture of warfare" and of raiding, thus needed to be replaced by other actions, expressively staged in a comparable manner. "Whenever he [Witbooi] planned a looting expedition, he would go out into the field in the evening and, in nocturnal solitude, await a divine revelation. Often, he would stay out for several days, and after returning - depending on the mission which he had received - either give the order to mount up, or to wait a while. The troop would then ride forth on the day which he had determined." (Conradt 2006 [1905/06]: 126) Divine protection for looting operations, in place of the spiritual protection symbolized by the Khoekhoe amulets, was concretized in an action which Witbooi performed ostentatiously. His universally visible retreat into the wilderness and his return from there was designed to provide certainty that the raid could be carried out with God's blessing.

In his Christian prophetic conception of identity and the "internalization" of faith, which he demanded of his followers, Witbooi banned all magical-cultic practices of warfare and raiding among his warriors which had grown out of the spiritual world of the Khoisan and persisted in the Christian-dominated everyday life. However, he did leave one central area of pre-Christian Khoisan religiosity untouched: he allowed the ancestors, with whom he himself communicated, to retain their place in the cosmological order of the Khoekhoe. Witbooi followed the mission of the ancestors to move northward into Herero land, the Promised Land of the forefathers, and thus tied them into a command passed on through him by God to unite the Nama-Oorlam and the Herero. The mission assigned by the ancestors and the command from God constituted the foundation for Witbooi's vision to found a new state.

\section{Living ancestry, living Christianity}

The explorer literature and missionary sources provide many indications that in warfare, the Nama-Oorlam did everything they could to ensure that no dead were left behind on the battlefield, a practice that can be seen as part of the "strategy of invisibility" and is typical for spatial use of small-scale warfare (cf. Klute 2013: 424ff. et sqq.). Aside from the strategic purpose of denying the enemy information about one's losses, and hence one's combat strength, this practice was designed, first, to preclude the purported Herero practices of mutilation and cannibalism, and second, and very importantly, to permit burial and thus ensure that the dead warriors would find peace, and not wander about as ghosts causing mischief. The practice of warfare also

17 Hendrik Witbooi to Jakob Irle, Feb. 17, 1888, recorded and translated by Johannes Olpp 1897 [1904], RMG 1.404 [5], in Möhlig 2007: 199. 
contained fixed pre-Christian elements of faith, above all with regard to dealings with the deceased.

The grave, an instable and ambivalent intermediate zone between the world of the living and that of the dead, is per se a liminal space where descendants and ancestors can interact directly (Harrington 2013: 86). The tomb was also for Hendrik Witbooi the place where he came into contact with the 'living dead,' those recently deceased generations which had not yet lost their 'personal immortality' and could still be considered ever so close to their 'living surviving' so that they were remembered by name and experienced as 'good spirits' who visited the living in dreams and visions and informed them of their expectations and orders (Mbiti 1969: 74ff.).

It is reported of Hendrik Witbooi that as long as he lived in Gibeon, he often visited the grave of his grandfather and talked to him, hoping for inspiration and meditation (Helbig and Hillebrecht 1992: 11). A report by missionary Heidman takes up on rumours about Witbooi's communication with his forefathers, while also reflecting the missionaries' growing distance and lack of understanding of their former protégé and church elder Hendrik Witbooi and his prophetic movement.

Recently Manasse of Hoachanas has sent the message that Hendrik Witbooi
had started his way north with a military force. In a dream apparition, he was
given the command to catch Maherero. According to the latest rumors, Hendrik
has not yet set off, but is preparing himself for it. His eccentricities must have
progressed alarmingly. It is told that he stops often and for a long time at the
grave of his grandfather and during this time he takes neither food nor drink.
There he receives revelations and instructions which are by no means harmless
in nature. Starting at his own boatyard, he will apparently kill several people in
different places and chase away Manasseh and the red people of Hoachanas. On
Rehoboth finally he is supposed to shoot Maherero so that peace would be fully
restored in the land. Should he refuse to fulfil this command, then it would cost
him his life.

Witbooi's conviction of the ancestors' power and of having to pay obedience to their command might be in striking homology with the power he contributed to God's instructions, which - according to his conviction - pertained equally to war and peacemaking. "Ancestry related practices are techniques for experientially engaging with the socially constituted past." (McCall 1995: 258). But they also allow dealing with the socially constructed presence. Ancestors can be perceived as actors that influence the living, but who can in turn also be influenced and drawn on for one's own intended purposes. The fact that Hendrik Witbooi received his instructions for his politicoreligious entreprise at the grave of his grandfather, i.e. the site of interaction with the ancestors, may have given him legitimacy to accept his mission in the eyes of his non-Christian followers. By retained his individual ancestry practices, the charismatic warlord concretized and relocalized his religiously legitimized authority, which he believed to have been endowed with by the Christian God. Because of his abstract and non-localized nature, this God was put to the test by the Nama-Oorlam warriors who stood at a distance to Christianity, such when their intention to attack a missionary

18 Heidmann, Rehoboth, October 24, 1884, National Archives of Namibia, Quellen zur Geschichte Südwestafrikas (H. Vedder, and E. Meier), 22 A: pp. 157 [303], unpublished typescript. 
station went beyond political and economic interests, but was above all about this God of the Christians 'showing' himself to them and 'prove' himself as a power of protection or destruction. ${ }^{19}$

Even though it is generally accepted that the Nama-Oorlam were largely Christianized in the $19^{\text {th }}$ century, the mission reports draw a more complex picture. All shades of religiosity can be found in the sources, from the maintaining of the precolonial Khoekhoe religion, especially by some Nama groups, to the plain rejection of Christianity or its purely strategic use, ${ }^{20}$ and the acceptance of Christian faith out of pure conviction. This plurality of values and worldviews could exist in tolerant coexistence but equally lead to internal and intercommunity tensions, discursively negotiated and confrontationally settled in the campaigns and raids of various NamaOorlam groups with each other and against the Herero. As mentioned, Hendrik Witbooi included members of other Nama-Oorlam groups in his komandos and appeared to have gathered, alongside his own followers who practiced Christianity, also people rooted in the indiginous religious culture and opting for magico-spiritual practices as well as Christian-minded people who, in his eyes, were apostates of 'true' Christianity:

... Of those who ... agreed with Hendrik and adhere to him, it is said that they obtain salvation (Seeligkeit), even if they are still totally heathen. ... Those who do not want to be affiliated right away, but who say, 'We first want to see how you will fare, and if you are well, we will join later, 'will be told: No one can follow us later, the Way will be closed behind us, and it will rain fire from the heavens upon all who stay here and they will perish. ${ }^{21}$

With a mixture of threat and promise, Hendrik Witbooi asked for the loyalty of his followers, in particular the Witbooi, who, against the background of a fatherson conflict over political supremacy, were faced with the decision to support either Hendrik Witbooi's father Moses, the politically weak, but still nominal chief (Kaptein), or to follow his son on his trek to the North. Witbooi demanded an uncompromising attitude. To those who did not immediately and completely join him, the 'Way' would remain forever closed.

Furthermore, the departure to the north had to be enforced against the Rhenish Missionary Society, represented in Gibeon by the missionary Rust, who tried to persuade the Witbooi to stay. ${ }^{22}$ When meeting with the mission, the local population opposed not only the intrusion of the missionaries in their daily life, it also struggled to maintain control of space and place (see Comaroff and Comaroff 1991: 310). The "missionary enthusiasm for stable peasant societies to produce remarkably microcosmic "village

19 This was taken up, for instance, by the report of C. Schmitz, Die Otjimbingue-Chronik mit Blick auf die Nachbarstationen, 1863, RMG 2.588 C/i8: 144-145.

20 Such as the possibility to profit from the mission which engaged in long-distance-trade (Wallace and Kinahan 2011: 109).

21 RMG 2.580b, Ci/2a, Rust sen., Gibeon, 01 July 1885: 83 [77].

22 The missionaries of the London Missionary Society (LMS) had tried before to impose a policy of rederning the Khoekhoe pastoralis sedentary, after establishing their first missionary stations north of Oranje in today's Namibia in 1806. Their actions led to serious conflicts with the Khoikhoi and regularly to the abandonment of the missionary station. (Dedering 1993: 56). 
Christianities" (Ranger 1993: 66) collided with the Witbooi movement's desire to extend over wider territorities, a desire equally characteristic for other movments of African independent Christianity (Ibid.).

The interconnectedness of politics and religion, characteristic for prophetic movements (see i.a. Adas 1979), is reflected by Witbooi's testimonies. A letter to the missionary Irle, in which Hendrik Witbooi explains the "content of the trek and war," clearly reveals how political interests, sacral mission, and - in the field of religion ancestral and divine references intersected in two ways in Witbooi's politico-religious mobilization.

This trek stems from our old late Captain David Witbooi, ... (who) moved north
and came to Gibeon to rest there first and then move on. At that time of rest,
I have known with certainty that the old captain will rest there at Gibeon and
even his soul, and that he will die at Gibeon, and that I should continue as a
predecessor to continue with this people of Kowesi and move to the north, when
the time is full. Thus this trek is an old trek ...

Hendrik Witbooi proceeds with how the missionary Olpp suggested to Captain David Witbooi and his great men (Großmänner) to build a church, but the latter refused on the grounds that the church would prevent them to continue their trek. But the church was built nonetheless on Hendrik Witbooi's "responsibility" and based on the belief that it "will not prevent us once the time comes to move on. The new church will bring us great blessing for soul and body as provision of all spiritual blessings. ... We moved on in the power of this blessing, and in this power I make war, when I go into war." 23

Witbooi had not let the missionaries in on the military implementation of following the 'Way' and the time of departure to the north, despite their insistent inquiries. But he mentioned to them the religious side of his mission. Despite his growing alienation from the Rhenish Missionary Society and its representatives, he apparently assumed a level of common understanding rooted in the Christian faith, even if he increasingly withdrew from it. On the other hand, Witbooi did not seem to let missionaries partake in his interaction with the ancestors, a world that was not theirs. Although he did make in vague utterances to his former 'teachers' about his ancestral mission, such as "continuing" the "great work" of his grandfather (Menzel 2000: 90f.), he did not seem to communicate the actual act of ritualized exchange. In his own testimonies and letters, Witbooi noted how he entered into a dialogue with God. However, we know only from second or third-hand reports that he visited the grave of his grandfather and made contact with the ancestors. Whether the meaning of this location might even have been double-binded for him - in the sense that it enabled him to enter into a relationship with God and the living dead - must remain open.

Setting off from Gibeon, Hendrik Witbooi de-territorialized the site of ancestor worship. With his departure for "the North," 24 the divine "instruction" to move to the Promised Land of the forefathers took the place of the direct interaction with the dead at the graveside. The establishment of contact with God and the ancestors, it seems at first

23 February 17, 1888, in RMG 1.404: 48b-51, quoted from Menzel 2000.

24 On Witbooi's move to the North, its political, biographical and intra-family backgrounds, and particularly his struggle with his father over the captaincy, see i.a. Dedering 1993, Menzel 2000, Reeh 2000. 
glance, was now no longer 'exclusively' tied to a ritually specified communication site, such as the grave. An immanent act was thus transcendentalized and simultaneously re-materialized in the "Way" - a key concept in Witbooi's awakening experience. As Witbooi described it:

I again experienced the power of our Almighty God, inexpressible and wonderful, as He delivered me and my three men: When the Herero rose and surrounded us in order to kill us, they suddenly did something quite unexplainable even to themselves: instead of killing me, they released me. ${ }^{25}$ They gave me a mare and told me to be off. So I set for home. And when I came to the pass of the great // Khaniguakha Mountains, I received three amazing words trough a voice which spoke to me. This was on 23 August 1880:

1.The time is fulfilled.

2. The way is opened

3. I lay a heavy task on you." 26

This famous passage from Witbooi's notes, written in Cape Dutch, has been theologically interpreted in the context of his Christian beliefs. However, the passage can also be interpreted in a number of other ways. The "Way" could, in a spatially abstracted continuation, also be the "Auld Way," mentioned above, which stands for an interrupted peregrination and asks for a 'reopening'. Similarly, but more localized, it might be the "Way of the ancestors," which Hendrik Witbooi, as stated at the outset, located in a conversation with the prospector Schwarz as leading from the mountainous area of the Kuisib Valley up to the Hoornkrans plateau. The "Way" as a territorial marker, which, in its metaphoric significance, becomes a "memorial symbol" (Assmann 2007: 257) defining the collective identity of the Witbooi, and refers to the migration history and also to the migration mission of their charismatic leader.

It may be no coincidence that Hendrik Witbooi receives his divine prophetic message precisely when he passed over a ravine, a key place where the Khoekhoe prayed to Heitsi-Eibib, the Nama referred to as their 'great-grandfather.' As mentioned, the graves of that mythical ancestor with its gift of prophecy and the power of victory over all his enemies has been situated "in the narrow mountain passes on both sides of the road" (Schapera 1930: 384). The multidimensional character of the location could be another indication for a lived religious diversity, which can be found vestigially in Hendrik Witbooi's agency, even he understood himself resolutely as a Christian.

Prophecy is attributed significance in the biblical narratives (see amongst others Abioje 2010, Redding 2010) as well as ancesterhood, too. Ancestral reference is of central importance in the Old Testament, with Abraham as the "spiritual ancestor" 27 of the children of Israel. The close connection between the dead and living generations - deeply-seated in Nama-Oorlam pre-Christian religious experiences - and the belief

25 The background to the experience referred to here was a case of cattle-rustling which escalated into a conflict between the Nama/Oorlam and the Herero, and led Herero Chief Maharero to order the killing of all Nama/Oorlam in his territory, on August 23, 1880. See e.g. Henrichsen 2011: 168.

26 Hendrik Witbooi in The Hendrik Witbooi Papers, Lau 1989: 39.

$27 C f$. also the cross-cultural hermeneutic study by the theologian Kamudzandu (2010). 
in the intersection of the supernatural and natural world mediated by the chosen ones merged into the Christian understanding of identity.

Of similar cross-cultural symbolism as the Way was also the Light, which, in the cosmic religious Khoisan view of the world was attributed to Tsui//goab, the God who protected humans and animals and brought rain and fertility. The 'Light' is mentioned in a passage that can be seen as a key scene in Witbooi's changing religious understanding. In this passage, the missionary J. C. Friedrich Heidmann reports on a conversation between Kaptein Hermanus van Wijk, Hendrik Witbooi and Samuel Isaak of Gibeon, whom he paraphrases:

\begin{abstract}
He said that they had been sent by the Lord to force the Herero, arms in hand, to make peace; that he came on like David, and in his spirit; that a light guided them on their march, and led them to Rehoboth. Once, he said, when they turned off from the way, believing that Maharero was still on Guru-Manas, the light suddenly disappeared, and the way became dark, and the light only appeared again before them once they had returned to the way to Rehobeth. He said that their desire was not for the cattle of the Herero, but rather to fight for a better peace. $^{28}$
\end{abstract}

Like the cloud that moved in front of the Israelites in their journey out of Egypt, the Light can be seen as one of the media of God which creates a transition from the divine to the human, and in which the God of the Old Testament manifests himself (Assmann 2007: 255). "The Word becomes the Light. That which is heard becomes that which is seen." ${ }^{29}$ Like this shift of the primacy, in the Old Testament, of "that which is heard" - the dictation of the Ten Commandments - to the primacy of "that which is seen," Witbooi's prophetic movement carried out a shift from the believe in Scripture to the belief in revelation. The missionary Rust, in a letter to the mission headquarters, reported on the state of the "movement," and "how far the zealotry (Schwärmerei) has gone," as follows: "It is said that 'The Word of God,' which is in the Bible, has been repealed, it no longer has any force or validity for us; we have to hold to our revelations; that is the Word of God." ${ }^{30}$ When Rust confronted Witbooi with this attitude on the part of his followers, he "denied this." But even his belief in salvation did not entirely replace his belief in Scripture, the former certainly did become central to the religious conception of the Witkam, as can be clearly seen from Witbooi's own writings. It was his religious policy measures and his revelation-based faith which would ultimately result in a secession from the German Missionary Society and a turn toward an independent church.

\title{
Conclusion
}

Framing "charismatic experiences" - such as revelations, prophecy, visions or dreams - as part of Christian practice means to replace the "mind, body, and spirit 'trichotomy' associated with Western thought" (Asamoah-Gyadu 2005: 47) by a

28 June 6, 1884: 5, in RMG 1.601b: 43-47, quoted from Menzel 2000: 4.

29 Popitz 2000: 87, here quoting the Judeo-Hellenistic religious philosopher Philo of Alexandria.

30 Jan. 7, 1885: 11-12, in RMG 1.621: 5b-7, quoted from Menzel 2000: 74. 
holistic worldview. In the realm of conflict between sublimation and abstractification which Christianity demanded ( $c f$. Assmann 2007: 272), and the concretization of the absent, which was, in the indigenous Khoekhoe belief, materialized at the graveside as the site of interaction with the ancestors, Hendrik Witbooi forged a link to the prophetic movement. The prophetic permits the visibility of abstract concepts of faith through substantial signs and actions.

Hence, a retrograde relationship can be ascertained in Witbooi's religious practice. Revelation-based faith is grounded in a personalized relationship with God, in which the person can make direct contact with God. Ancestor worship is also "a highly interactive, participatory religion" (Ephirim-Donkor 2010: X). So, the element of dialogue is characteristic for the transcultural disposition of both forms of religion which, here, can easily interact.

Hendrik Witbooi did not call for any "Christian-indigenous synchronicity," such as that which is propagated today in many post-colonial churches, for example among the Native Americans (Meiser 2013); indeed, he rejected it. Nonetheless, the question arises as to whether cross-cultural religious interactions were not characteristic of his ability to bind his followings to himself. For, as has been noted, he stressed certain elements of the religious which were in their symbolism of significance both for the adherents of Christianity and for those of the indigenous Khoekhoe religion.

Witbooi, justified his political-religious and military actions in the name of God, who, he claimed, revealed himself to him in his commands both for peace and for war. By re-forging ties to the ancestors, the charismatic leader created a second strain of legitimacy so that his move northward with his following was rooted both in an imagined past and in a visionary future.

\section{References}

AвıJoje, P.O., 2010. "Critical Prophecy and Political Leadership in Biblical, African and Islamic Worldviews”, Koers 75 (4), pp. 787-810.

Adas, Michael, 2009 [1979]. Prophets of Rebellion. Millenarian Protest Movments against the European Colonial Order. Cambridge et al.: Cambridge University Press [digitally printed version].

Alexander, James Edward, 1838. An Expedition of Discovery into the Interior of Africa, through the Hiterto undescribed Countries of the Great Namaquas, Boschmans, and Hill Damaras, 1. Philadelphia: E.L. Carey and Hart.

AltenA, Thorsten, 2003. 'Ein Häuflein Christen mitten in der Heidenwelt des dunklen Erdteils'. Zum Selbstund Fremdverständnis protestantischer Missionare im kolonialen Afrika 1884-1918. Münster: Waxmann.

Anderson, David and H. Johnson Douglas (eds), 1995. Revealing Prophets. Prophecy in Eastern African History. London et al.: James Currey.

Asamonh-Gyadu, Kwabena, 2005. African Charismatics. Current Developments within Independent Indigenous Pentecostalism in Ghana. Leiden/Boston: Brill.

Asante, Molefi K. and Ama Mazama, 2009. Encyclopedia of African Religion. London et al.: Sage.

Assmann, Aleida, 2007. "Gewalt und das kulturelle Unbewusste. Eine Archäologie des Abendmahls" in Wolfgang Palaver, Andreas Axenberger and Kristina Stöckl (eds), Aufgeklärte Apokalyptik: Religion, Gewalt und Frieden im Zeitalter der Globalisierung, pp. 253-278. Insbruck: University Press.

Behrend, Heike, 1993. Alice und die Geister. Krieg im Norden Ugandas. München: Trickster. 
-, 2011. Resurrecting Cannibals. The Catholic Church, Witch-Hunts and the Production of Pagans in Western Uganda. Woodbridge, Rochester: James Currey.

Beidelman, Thomas O., 1982. Colonial Evangelism. A Socio-Historical Study of an East African Mission at the Grassroots. Bloomington: Indiana University Press.

Cole, Jennifer and Karen Middleton, 2001. "Rethinking Ancestors and Colonial Power in Madagascar", Africa: Journal of the International African Institute 71 (1), pp. 1-37.

Comaroff, Jean, 2012. "Religion, Society, Theorie", Religion and Society 3, pp. 5-16.

Comaroff, Jean and John Comaroff, 1991. Of Revelation and Revolution. Christianity, Colonialism, And Consciousness in South Africa. Vol. 1. Chicago and London: University of Chicago Press.

CONRADT, Ludwig, 2006 [1905/06]. Erinnerungen aus zwanzigjährigem Händler- und Farmerleben in Deutsch-Südwestafrika. (Herausgegeben, kommentiert und mit einer Einleitung versehen von Thomas Keil). Göttingen/Windhoek: Klaus Hess.

Dedering, Tilman, 1993. "Hendrik Witbooi, the Prophet”, Kleio 25 (January), pp. 54-78.

-, 1997. Hate the Old and Follow the New. Khoekhoe and Missionaries in Early Nineteenth-Century Namibia. Stuttgart: Franz Steiner-Verlag.

Elbourne, Elizabeth, 1992. "Early Khoisan Uses of Mission Christianity", Kronos: Journal of Cape History, 19 , pp. 3-27.

Ephirim-Donkor, Anthony, 2010. African Religion Defined. A Systematic Study of Ancestor Worship among the Akan. Lanham: University Press of America.

Glocke-Daffa, Sabine, 2001. “Wenn du hast, musst du geben”. Soziale Sicherung in Ritus und im Alltag bei den Nama von Berseba/Namibia. Münster et al.: Lit.

HaHn, Theophilius 1881 [2000]. Tsuni-Goam. The Supreme Being oft the Khoi-Khoi. London: Trübner and Co, Ludgate Hill, repr. London: Routledge.

Hardung, Christine and Trutz von Trotha, 2013. "Komando und 'Bande'. Zwei Formen von Gewaltgemeinschaften im südwestlichen Afrika des ausgehenden 18. und 19. Jahrhunderts" in Winfried Speitkamp (ed.), Gewaltgemeinschaften. Von der Spätantike bis ins 20. Jahrhundert, pp. 275-296. Göttingen: V\&R unipress.

-, 2014. "Der Krieg hat viele Stimmen. Materiale Dimensionen von Kommunikation in Krieg und Razzia der Nama/Oorlam im südwestlichen Namibia des 19. Jahrhunderts", Anthropos 109, pp. 1-20.

Harrington, Nicola, 2013. Living with the Dead. Ancestor Worship and Mortuary Ritual in Ancient Egypt. Oxford and Oakville: Oxbow Books.

Helbig, Ludwig and Werner Hillebrecht, 1992. The Witbooi. Windhoek: Longman Namibia.

Hellberg, Carl J., 1997. Mission, Colonialism and Liberation: The Lutheran Church in Namibia 1840-1966. Windhoek: New Namibian Books.

Henrichsen, Dag, 2011. Herrschaft und Alltag im vorkolonialen Zentralnamibia. Das Herero- und Damaraland im 19. Jahrhundert. Basel/Windhoek: Basler Afrika Bibliographien/ Kuiseb Verlag.

Hillebrecht, Werner, 2004. "Hendrik Witbooi: Ikone des antikolonialen Widerstands und des unabhängigen Namibia" in Larissa Förster, Dag Henrichsen and Michael Bollig (eds), Namibia - Deutschland. Eine geteilte Geschichte. Widerstand - Gewalt - Erinnerung, pp. 144-153. Köln: Rautenstrauch-JoestMuseum.

Jules-Rosette, Bennetta, 1994. "The Future of African Theologies. Situating New Religious Movements in an Epistemological Setting”, Social Compass 41 (1), pp. 49-65.

Kamudzandu, Israel, 2010. Abraham as Spiritual Ancestor. A Postcolonial Zimbabwean Reading of Romans 4. Leiden, Boston: Brill. 
KIENEtZ, Alvin, 1977. "The Key Role of the Orlam Migrations in the Early Europeanization of South-West Africa (Namibia)", The International Journal of African Historical Studies X (4), pp. 553-572.

Kleinschmidt, [Johannes], 1894. "Hendrik Witbooi. Ein Beitrag zum Verständnis der Wirren in DeutschSüdwestafrika”, Globus. Illustrierte Zeitschrift für Länder- und Völkerkunde, LXVI (10), pp. 149153.

KLute, Georg, 2013. Tuareg-Aufstand in der Wüste. Ein Beitrag zur Anthropologie der Gewalt und des Krieges. Köln: Köppe.

Kolb, Peter[en] 1738 [1903]. The Present State of the Cape of Good-Hope, $2^{\text {nd }}$ ed. London: W. Innys and R. Manby.

KöSSLER, Reinhart, 2010. "Political Intervention and the Image of History: Communal Memory Events in Central and Southern Namibia" in André du Pisani, Reinhart Kössler and William A Lindeke (eds), The Long Aftermath of War - Reconciliation and Transition in Namibia, pp. 371-402. Freiburg: Arnold-Berstraesser-Institut.

LAU, Brigitte, 1887. Southern and Central Namibia in Jonker Afrikaner's Time. Windhoek: National Archives.

-, 1989. The Hendrik Witbooi papers. Windhoek: National Archives of Namibia.

Lichtenstein, Henry, 1812. Travels in Southern Africa in the Years 1803, 1804, 1805, and 1806. London: printed for Henry Colburn.

Lindenfeld, David and Miles Richardson, 2012. "Introduction. Beyond Conversion and Syncretism" in David Lindenfald, and Miles Richardson (eds), Beyond Conversion and Syncretism. Indigenous Encounters with Missionary Christianity, 1800-2000, pp. 1-23. New York, Oxford: Berghahn Books.

Lотн, Heinrich, 1987 [1985]. Vom Schlangenkult zur Christuskirche. Religion und Messianismus in Afrika. Frankfurt am Main/Berlin: Fischer/Union Verlag VOB.

MвiтI, John S., 1969. African Religions and Philosophy. London: Heinemann.

Mccall, John C., 1995. "Rethinking Ancestors in Africa", Africa: Journal of the International African Institute 65 (2), pp. 256-270.

MeIsER, Anna 2013. “Ich trinke aus zwei Flüssen”. Zur Logik transkultureller Prozesse bei christlichen Achuar und Shuar im oberen Amazonien. Stuttgart: Kohlhammer.

MenZel, Gustav, 2000. “Widerstand und Gottesfurcht”. Hendrik Witbooi-eine Biographie in zeitgenössischen Quellen. Köln: Rüdiger Köppe.

Meyer, Birgit, 1999. Translating the Devil. Religion and Modernity among the Ewe in Ghana. Edinburgh: Edinburgh University Press.

-, 2012. "Christianity in Africa. From African Independent to Pentecostal-Charismatic Churches", in Elias Kifon Bongmba (ed.), The Wiley-Blackwell Companion to African Religions, pp. 153-170. Malden (Ma) et al.: Wiley-Blackwell.

MöHLIg, Wilhelm J.G. (ed.), 2007. Die Witbooi in Südwestafrika während des 19. Jahrhunderts. Quellentexte von Johannes Olpp, Hendrik Witbooi jun. und Carl Berger. Köln: Rüdiger Köppe.

Mudimbe, V.Y. and Susan M. Kilonzo, 2012. "Philosophy of Religion on African Ways of Believing", in Elias Kifon Bongmba (ed.), The Wiley-Blackwell Companion to African Religions, pp. 41-61. Malden (Ma) et al.: Wiley-Blackwell.

Penn, Nigel, 2005. The Forgotten Frontier. Colonist and Khoisan on the Cape's Northern Frontier in the $18^{\text {th }}$ Century. Athens/Cape Town: Ohio University Press/Double Storey Books.

PopITz, Heinrich, 2000 [1997]. Wege der Kreativität. Tübingen: Mohr Siebeck.

Ranger, Terence, 1993. "The Local and the Global in Southern African Religious History" in Robert W. Hefner (ed.), Conversion to Christianity. Historical and Anthropological Perspectives on a Great Transformation, pp. 65-98. Berkeley: University of California Press. 
Redding, Sean, 2010. “Maybe Freedom Will Come From You': Christian Prophecies and Rumors in the Development of Rural Resistance in South Africa, 1948-1961", Journal of African Religion in Africa 40, pp. 163-191.

ReEH, Günther, 2000. Hendrik Witbooi. Ein Leben für die Freiheit. Zwischen Glaube und Zweifel. Köln: Rüdiger Köppe.

Schapera, Isaac, 1930. The Khoisan Peoples of South Africa. Bushmen and Hottentots. London: Routledge.

Schмidt, Sigrid, 1986. "Heiseb - Trickster und Gott der Nama und Dama in Südwestafrika/Namibia" in Rainer Vossen and Klaus Keuthmann (eds), Contemporary Studies on Khoisan. Part 2, pp. 205-256. Hamburg: Helmut Buske Verlag.

SCHREYer, Johann, 1679/81. "Reise nach dem Kaplande und Beschreibung der Hottentotten 1669-1677" in S.P.L’ Honoré Naber (ed.), (1931), Reisebeschreibungen von deutschen Beamten und Kriegsleuten im Dienst der niederländischen west- und ost-indischen Kompagnien 1602-1797, [Bd.] VII).

Schwarz, Bernhard, 1889. Im deutschen Goldlande. Reisebilder aus dem südwestafrikanischen Schutzgebiet. Berlin: Hermann Peters.

Steadman, Lyle B., Craig T. Palmer and Christopher F. Tilley, 1996. "The Universality of Ancestor Worship", Ethnology 35 (1), pp. 63-76.

TAll, Emmanuelle Kadya, 2012. Le Candomblé de Bahia. Miroir baroque des mélancholies postcoloniales. Paris: Cerf.

Tishren, Joel E., 2007. “The History of Prophecy in West Africa: Indigenous, Islamic, and Christian”, History Compass 5/5, pp. 1468-1482.

Wallace, Marion and John Kinahan, 2011. A History of Namibia. Cape Town: Jacana.

WIRZ, Albert et al., 2003. "Transculturation - Mission and Modernity. A Manifesto" in Adam Jones (ed.), Transculturation: Mission and Modernity in Africa, pp. 3-23. Leipzig: Institut für Afrikanistik.

Wright, Marcia, 1995. "Maji Maji. Prophecy and Histiography” in David M. Anderson and H. Johnson Douglas (eds), Revealing Prophets, pp. 124-142. London et al.: James Currey. 